\title{
SIDO-CHAR SEBAGAI PEMBENAH KERACUNAN Fe PADA TANAH SAWAH
}

\author{
Sido-char as an Ameliorant of Fe Toxicity in Paddy Fields
}

\author{
Catherin Anggi Tiara*, Fitria Dita Rahmatina, Rahmatul Fajrianeldi, Lusi Maira \\ Universitas Andalas, Padang \\ *)Penulis korespondensi: siburiancatherin21@gmail.com
}

\begin{abstract}
Solok Regency is known as a food production centre of the community of West Sumatra and has extensive volcanic paddy fields. Paddy fields have problems of one that is the toxicity of $\mathrm{Fe}$ at the time of the decrease in $\mathrm{pH}$, thereby resulting in low available $\mathrm{P}$ (Phosphate) and can decrease the production of rice. This research aimed to get the right combination of siderophore-producing bacteria by growing rice husk bio-char media in overcoming toxicity of iron (Fe) in the land of paddy fields in Solok Regency, and to get a pure siderophore bacterial isolate without the use of the media biochar in overcoming toxicity of Fe on paddy fields. The results of this research showed that the addition of the siderophore bacteria by using rice husk biochar could reduce the toxicity of $\mathrm{Fe}$ as well as improving soil available $\mathrm{P}$ content of paddy field. The best combination was obtained for $10 \mathrm{ml}$ of siderophore bacterial isolate and $25 \mathrm{~g}$ of rice husk biochar.
\end{abstract}

Keywords: biochar, siderophore, toxicity of $\mathrm{Fe}$, volcanic paddy fields

\section{Pendahuluan}

Kabupaten Solok dikenal sebagai sentra produksi padi masyarakat di Sumatera Barat. Total luas lahan sawah di Kabupaten Solok sebesar $23.426 \mathrm{Ha}(32.36 \%)$ dari 72.370 ha total luas lahan pertanian di Kabupaten Solok (BPS, 2017). Periode tahun 2016 - 2017, komoditas padi mengalami kenaikan produktifitas dari 6,60 ton/ha menjadi 6,67 ton/ha (BPS, 2018). Menurut Sudarsono et al., (2010), tingkat produktifitas padi di Kabupaten Solok tersebut masih tergolong rendah dibandingkan dengan potensi hasilnya yang dapat mencapai $7 \mathrm{t} \mathrm{ha}$. Jumlah penduduk Kota Solok dari tahun 2014 - 2017 terus mengalami peningkatan. Pada tahun 2014 jumlah penduduk Kota Solok adalah 64.819 jiwa, tahun 201566.106 jiwa, tahun 2016 67.307 jiwa dan pada tahun 2017 jumlah penduduk kota Solok adalah 68.602 jiwa dan kepadatan penduduknya mencapai 1.190 jiwa $\mathrm{km}^{-2}$ (BPS, 2018).

Tanah sawah merupakan salah satu sumber daya lahan utama dalam memproduksi beras sebagai kebutuhan pokok Nasional. Tanah sawah di kabupaten Solok didominasi dari bahan induk vulkanis, Karena daerah tersebut berada di kaki gunung merapi yaitu gunung Talang. Permasalahan utama pada tanah sawah vulkanis adalah tingginya kandungan besi $\left(\mathrm{Fe}^{+3}\right)$. Fiantis (2010) menjelaskan bahwa kandungan abu vulkanis Gunung Talang memiliki kadar $\mathrm{Fe}_{2} \mathrm{O}_{3}$ sebesar $5,39 \%$, urutan 3 terbesar setelah $\mathrm{SiO}_{2}$ dan $\mathrm{Al}_{2} \mathrm{O}_{3}$. Selanjutnya Nanda (2018) dengan pemanfaatan citra landsat 8 untuk identifikasi besi $(\mathrm{Fe})$ pada sawah vulkanis gunung Talang terdapat beberapa sampel yang secara visual menunjukkan warna kekuningan (dark yellowish brown 10 YR 3/4, 4/4 dan 4/6), hal ini disebabkan oleh kadar besi lebih dominan 
mempengaruhi warna dibandingkan faktor lainnya.

Besi (Fe) merupakan salah satu unsur hara mikro yang dibutuhkan tanaman, dan unsur keempat yang paling banyak di bagian litosfer (Datnoff et al., 2007). Pada kondisi tereduksi, besi dapat menyebabkan keracunan pada tanaman padi, serta terjadi retensi hara pada tanah sawah. Mekanisme keracunan besi (Fe) pada sawah yaitu dengan terhambatnya serapan hara yang disebabkan tidak berkembangnya perakaran, karena perakaran tersebut diselimuti oleh besi oksida. Hal ini mengakibatkan terganggunya fungsi akar dalam menyerap unsur hara dari dalam tanah sehingga pertumbuhannya terhambat dan dapat mengakibatkan produksinya rendah atau bahkan tanaman tidak berproduksi. Keracunan besi $(\mathrm{Fe})$ pada lahan sawah dapat menurunkan hasil padi 52-75 \% (Pusat Penelitian Tanah, 2004). Toksisitas besi (Fe) pada padi yang disebabkan oleh tingginya kadar besi $(\mathrm{Fe})$ larut merupakan kendala utama dalam produksi padi. Keracunan besi merupakan momok yang sangat menakutkan petani sawah karena dapat menyebabkan gagal panen.

Melihat kasus yang terjadi, penulis mencoba membuat suatu inovasi untuk mengurangi efek negatif dari kelarutan besi yang tinggi pada tanah sawah yang beresiko mengalami keracunan besi terutama pada lahan yang digenangi secara terus menerus dengan mengaplikasikan bakteri penghasil siderofor dan biochar sekam padi sebagai media tumbuhnya (Sido-Char).

Bakteri penghasil siderofor selain perannya sebagai agen pengangkut besi (III), juga berkemampuan sebagai pengendali mikroba patogen (biocontrol). Berkurangnya kadar Fe pada tanah berakibat menurunnya aktifitas beberapa bakteri patogen, sehingga keberadaan patogen dapat dikendalikan. Selain itu besi merupakan elemen penting dalam perkembangan penyakit, sehingga dengan terikatnya besi oleh siderofor maka patogen kurang mampu menginfeksi, sehingga menghambat perkembangan penyakit Fe sangat dibutuhkan oleh bakteri patogen untuk metabolisme.

Siderofor juga aktif sebagai faktor pertumbuhan dan beberapa diantaranya berpotensi sebagai antibiotik (Neilands,1981).
Bakteri Siderofor juga dapat berperan sebagai bakteri pelarut posfat sehingga unsur hara Posfat lebih tersedia. Bakteri siderofor dapat menjadi bakeri pelarut posfat karena ketika Fe diikat oleh siderofor maka unsur hara $\mathrm{P}$ akan lebih tersedia. Unsur $\mathrm{Fe}$ yang tinggi dapat mengikat basa basa dalam tanah salah satunya unsur $\mathrm{P}$, sehingga tidak dapat diserap oleh tanaman. Dalam penggunaan bakteri siderofor membutuhkan media yang tepat. Media tumbuh yang diharapkan adalah media yang memiliki kadar C yang tinggi sebagai sumber carbonnya serta dapat bertahan lama. Media yang dianggap tepat dalam hal ini adalah biochar sekam padi.

Biochar merupakan arang hayati dari sebuah pembakaran tidak sempurna sehingga menyisakan unsur hara yang dapat menyuburkan lahan Gani (2009). Nurida et al. (2010) menambahkan biochar sekam padi memiliki kandungan C-organik $>35 \%$ dan kandungan unsur makro seperti $\mathrm{N}, \mathrm{P}$ dan $\mathrm{K}$ yang cukup tinggi. Oleh karena itu, limbah sekam padi dapat diproses menjadi biochar yang dapat dikembalikan ke tanah sebagai bahan pembenah tanah selain itu biochar dapat menjadi media pertumbuhan dari bakteri siderofor. Karena bakteri siderofor dapat mempergunakan carbon yang berasal dari biochar menjadi makanannya.

Masalah kelebihan Fe telah banyak diatasi secara kimia dan fisika misalnya seperti penambahan bahan organik, penambahan pupuk, pengaturan air. Namun sejauh ini belum banyak penelitian tentang penanganan keracunan $\mathrm{Fe}$ ditinjau dari segi biologisnya dengan mengungkap peranan mikroba penghasil siderofor dalam mengkhelat besi sehingga penelitian ini sangat penting untuk dilakukan.

Tujuan dari penelitian ini adalah untuk mendapatkan kombinasi yang tepat dari bakteri penghasil siderofor dengan media tumbuhnya biochar sekam padi dalam mengatasi keracunan besi (Fe) pada tanah sawah di Kabupaten Solok, mendapatkan kemampuan isolat murni bakteri siderofor tanpa menggunakan media tumbuh biochar dalam mengatasi keracunan $\mathrm{Fe}$ pada tanah sawah serta mengetahui kemampuan dari biochar sekam padi dalam mengurangi keracunan Fe pada tanah sawah 


\section{Bahan dan Metode}

Penelitian ini dilakukan di rumah kaca Fakultas Pertanian Universitas Andalas. Sampel tanah diambil dari tanah sawah vulkanis di Nagari Salayo Tanang Bukik Sileh Kecamatan Lembang Jaya Kab. Solok. Bahan yang digunakan dalam penelitian ini adalah sampel tanah sawah, media NA(Nutrient Agar), TSA (Triptic Soy Agar), media kultur LB (LuriaBertain $)$, air kelapa, biochar sekam padi, Alkohol $70 \%$, aquadest, $\mathrm{KOH}, \mathrm{K}_{2} \mathrm{Cr}_{2} \mathrm{O}_{7}, \mathrm{HCl}$, $\mathrm{KCl}$ plastik wrap, alumunium foil. Isolat yang digunakan adalah isolat Bacillus sp. koleksi Rahmah (2015)

\section{Rancangan penelitian}

Penelitian dilaksanakan menggunakan Rancangan Faktorial yang disusun secara Acak Lengkap yang terdiri atasi 2 faktor, yaitu faktor $\mathrm{S}$ dan $\mathrm{B}$ dan diulang sebanyak 3 kali (Tabel 1). Faktor S (Bakteri Siderofor) terdiri atas $\mathrm{S} 0=$ Tanpa isolat bakteri, $\mathrm{S} 1=$ Isolat bakteri $10 \mathrm{ml}$, dan S2 = Isolat bakteri $20 \mathrm{ml}$. Faktor B (Biochar sekam padi) terdiri atas $\mathrm{B} 0=$ Tanpa biochar, dan $\mathrm{B} 1=$ Dengan biochar $25 \mathrm{~g}$.

Tabel 1. Kombinasi perlakuan

\begin{tabular}{c|c|c}
\hline \multirow{2}{*}{ Faktor S } & \multicolumn{2}{|c}{ Faktor B } \\
\cline { 2 - 3 } & B0 & B1 \\
\hline S0 & S0B0 (1) & S0B1 (1) \\
& S0B1 (2) \\
& S0B0 (3) & S0B1 (3) \\
\hline S1 & S1B0 (1) & S1B1 (1) \\
& S1B0 (2) & S1B1 (3) \\
\hline S2 & S1B0 (3) & S2B1 (1) \\
& S2B0 (1) & S2B1 (2) \\
& S2B0 (2) & S2B1 (3) \\
\hline
\end{tabular}

Data hasil pengamatan $\mathrm{Fe}$ tanah setelah diinkubasikan dianalisis secara statistik dengan menggunakan uji $\mathrm{F}$ untuk sidik ragamnya dengan taraf nyata $5 \%$. Jika berbeda nyata (F hitung lebih besar dari $\mathrm{F}$ tabel $5 \%$ ), maka dilanjutkan dengan uji Duncan's New Multiple Range Test (DNMRT) pada taraf 5\%.

\section{Pelaksanaan penelitian}

\section{Pengambilan Sampel Tanah}

Pengambilan sampel tanah sawah dilakukan pada lahan sawah di Kabupaten Solok secara Random Sampling. Tanah di ambil pada kedalaman $0-20 \mathrm{~cm}$ secara komposit, dan dimasukkan ke dalam kantong plastik.

\section{Persiapan tanah}

Sampel tanah yang diambil selanjutnya diaduk merata (homogen). Lalu ditempatkan dalam ember plastik masing-masing $5 \mathrm{~kg}$ sebanyak 18 satuan. Sampel tanah untuk analisis kimia tanah awal yang meliputi analisis $\mathrm{pH}, \mathrm{Fe}$, $\mathrm{N}, \mathrm{P}, \mathrm{K}$, C-organik, dikering anginkan, lalu diayak untuk analisis kimia tanah awal.

\section{Pembuatan biochar sekam padi}

Proses pembuatan biochar sekam padi tidak jadi menggunakan Drum yang diberi cerobong dikarenakan sulitnya dalam proses pembalikan sekam padi. Apabila sekam padi tidak dilakukan pembalikan maka sekam padi akan hangus. Oleh karena itu, peneliti memodifikasi alat sederhana yaitu dengan membuat tabung silinder dari seng plat kemudian diberi lubang disekeliling alat. Alat yang sudah dibuat kemudian diletakkan diatas alas yang sudah disediakan. Kemudian tabung silinder diisi dengan arang dari batok kelapa dan kayu. Setelah itu, sekam padi ditumpuk disekeliling alat. Kemudian sekam padi dibolak balik sampai seluruh sekam padi berubah warna menjadi hitam. Kemudian arang sekam padi 
yang masih panas disiram air agar idak berubah menjadi abu.

\section{Isolasi bakteri penghasil siderofor}

Isolasi bakteri penghasil siderofor tidak jadi dilakukan. Kendalanya adalah Chrome Azzurol untuk bahan pembuatan media membutuhkan waktu 3 bulan untuk pemesanannya. Oleh karena itu, peneliti menggunakan koleksi isolat bakteri dari Dr. Haliatur Rahma, SSi. MP. yang diperoleh dari rhizosfer akar tanaman jagung di Sukabumi. Jenis isolat bakteri yang diproleh adalah Baccilus Sp.

\section{Pemurnian dan peremajaan isolat bakteri siderofor}

Pemurnian (purification) bertujuan agar diperoleh biakan murni yang diinginkan tanpa ada kontaminan dari mikroba lain. Pemurnian isolat bakteri dilakukan dengan cara memindahkan bakteri menggunakan metode garis yang kemudian ditumbuhkan pada media agar TSA.

\section{Perbanyakan isolat bakteri penghasil siderofor}

Isolat bakteri siderofor yang sudah dilakukan pemurnian kemudian diperbanyak dalam media Luria-Bertaini (LB) kemudian dishaker selama 2x 24 jam.

\section{Pemberian perlakuan}

Sampel tanah dalam ember selanjutnya diberi perlakuan. Pemberian formulasi bakteri penghasil siderofor dan biochar sekam padi dengan dosis yang tertera dalam rancangan percobaan. Aplikasi formulasi bakteri dan biochar sekam padi dalam jumlah dan cara yang sama diulang sebanyak 3 kali dengan selang waktu 2 minggu.

\section{Tahapan analisis sampel tanah di laboratorium}

Analisis tanah yang dilakukan adalah: (1) analisis $\mathrm{pH}$ tanah dengan metode $\mathrm{pH}$ meter, (2) Uji kandungan $\mathrm{Fe}$ awal dengan metode Spektofotometri, (3) analisis C-Organik Tanah, (4) analisis kadar N, P, K tanah

\section{Hasil dan Pembahasan}

\section{Kadar Fe tanah sebelum inkubasi}

Berdasarkan hasil analisis tanah awal, Fe tanah sawah memiliki nilai yang berbeda beda dan termasuk dalam kategori yang tinggi. Lokasi pengambilan titik sampel adalah tanah sawah yang berbahan induk vulkanis.

Tabel 2. Kadar Fe tanah sebelum inkubasi.

\begin{tabular}{cccc}
\hline No & Sampel & $\begin{array}{c}\mathbf{F e}^{3+} \\
\text { (ppm) }\end{array}$ & $\begin{array}{c}\text { Fe-total } \\
\text { (ppm) }\end{array}$ \\
\hline 1 & S0B0 & 220 & 285 \\
2 & S0B1 & 193 & 268 \\
3 & S1B0 & 206 & 287 \\
4 & S1B1 & 214 & 277 \\
5 & S2B0 & 209 & 290 \\
6 & S2B1 & 216 & 289 \\
\hline
\end{tabular}

Tanah vulkanis merupakan tanah yang berasal dari letusan gunung api, pada saat gunung api meletus mengeluarkan tiga jenis bahan yaitu berupa padatan, cair, dan gas. Bahan-bahan tersebut nantinya akan menjadi bahan induk penyusun tanah. Besi hadir sebagai elemen keempat terbesar di bumi setelah Oksigen, Silikon dan Aluminium. Lithosfer (kulit bumi) mengandung $5.1 \% \mathrm{Fe}$ namun sangat sedikit dibutuhkan tanaman. konsentrasi besi dalam jaringan tanaman dinyatakan normal pada kisaran 100-200 ppm.Jumlah besi dalam tanah yang dapat tereduksi sangat banyak, yaitu 10 kali lebih banyak dari total unsur-unsur lain yang dapat direduksi. Akibatnya kelarutan Fe tinggi dan berpotensi menyebabkan keracunan pada padi sawah.Apabila kadar besi dalam tanah berada pada konsentrasi lebih dari 300 ppm, kondisi ini dapat menyebabkan keracunan pada tanaman padi. Ciri fisik tanah sawah yang memiliki kadar Fe yang tinggi dapat ditandai dengan air sawah yang berminyak dan berwarna kekuningan
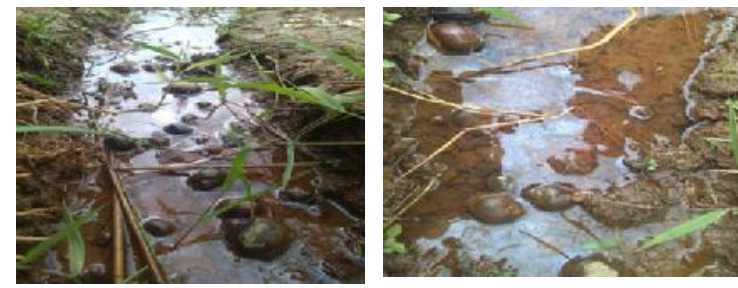

Gambar 1. Kondisi air tanah sawah dengan kandunga Fe tinggi. 


\section{Kandungan N, P, K Tanah sawah sebelum inkubasi}

Pengamatan kadar N.P dan $\mathrm{K}$ tanah sawah sebelum inkubasi disajikan pada Tabel 3. Pada Tabel 3 terlihat bahwa analisis N,P,K sampel tanah didapatkan hasil bahwa kadar Nitrogen dari 6 titik pengambilan sampel tinggi dan untuk Posfor dan Kalium fluktuatif. Hasil analisis menunjukkan $\mathrm{N}$ yang tinggi dan hal ini sejalan dengan apa yang dilakukan petani di lapangan. Petani padi sawah saat ini tidak lagi memberikan pupuk yang mengandung $\mathrm{N}$ di lapangan karena pemberin urea hanya akan berakibat pertumbuhan vegetatif sangan bagus tetapi pertumbuhan vegetatifnya tidak baik yang ditandai dengan turunya hasil gabah.

Tabel 3. Analisis N, P dan K tanah sawah sebelum inkubasi.

\begin{tabular}{|c|c|c|c|c|c|c|}
\hline Sampel & $\begin{array}{c}\text { N-total } \\
(\%)\end{array}$ & Kriteria & $\begin{array}{c}\text { P-total } \\
\text { (ppm) }\end{array}$ & Kriteria & $\begin{array}{c}\text { K-total } \\
(\%)\end{array}$ & Kriteria \\
\hline S0B0 & 0,74 & $\mathrm{~T}$ & 35 & S & 1 & $\mathrm{~T}$ \\
\hline S0B1 & 0,7 & $\mathrm{~T}$ & 19 & $\mathrm{R}$ & 1 & $\mathrm{~T}$ \\
\hline S1B0 & 0,69 & $\mathrm{~T}$ & 45 & $\mathrm{~T}$ & 0,9 & $\mathrm{~T}$ \\
\hline S1B1 & 0,72 & $\mathrm{~T}$ & 34 & S & 1 & $\mathrm{~T}$ \\
\hline S2B0 & 0,71 & $\mathrm{~T}$ & 13 & $\mathrm{R}$ & 0,89 & $\mathrm{~T}$ \\
\hline S2B1 & 0,73 & $\mathrm{~T}$ & 34 & S & 0,93 & $\mathrm{~T}$ \\
\hline
\end{tabular}

Hasil analisis kandungan posfor yang memiliki kadar yang secara keseluruhan sedang. Data ini sangat mendukung adanya indikasi $\mathrm{Fe}$ yang tinggi pada tanah sawah tersebut sehingga $\mathrm{P}$ yang ada didalam tanah dikhelat oleh $\mathrm{Fe}$ menjadi $\mathrm{Fe}-\mathrm{P}$ dan juga diikat oleh mineral alofan oleh tanah sawah vulkanis ini sehingga kurang tersedia bagi tanaman. Oleh sebab itu, ketika melakukan wawancara dengan petani dilokasi tersebut mereka menyatakan bahwa pemberian pupuk hanya 2 macam yaitu pupuk SP-36 dan pupuk SS. Kedua jenis pupuk ini adalah pupuk untuk unsur hara P.Untuk pupuk urea, mereka sangat jarang memberikannya karena kandungan $\mathrm{N}$ dalam tanah tinggi.

\section{Pembuatan biochar sekam padi dan analisis kandungan biochar}

Biochar sekam padi dibuat dengan alat sederhana yaitu dari plat seng yang dibentuk menjadi tabung silinder dan diberi lubang lubang kecil. Hasil analisisi kandungan biochar sekam padi disajikan pada Tabel 4. Komposisi kimia yang terkandung didalam biochar yang telah dibuat adalah C-organik 45,06\%, $\mathrm{N}$-total $0,31 \%$, P total $0,07 \%$ dan $\mathrm{k} 0,28 \%$.Biochar dapat ditambahkan ke dalam tanah dengan tujuan untuk meningkatkan fungsi tanah dan mengurangi emisi dari biomassa yang secara alami terurai menjadi gas rumah kaca. Biochar juga mempunyai fungsi sebagai pengikat karbon yang cukup besar. Penelitian yang dilakukan Gani, (2009) menunjukkan bahwa dalam tanah, biochar menyediakan habitat bagi mikroba tanah dan umumnya biochar yang diaplikasikan dapat tinggal dalam tanah selama ratusan atau bahkan ribuan tahun.

Tabel 4. Kandungan biochar sekam padi

\begin{tabular}{c|c}
\hline Kandungan & Nilai $\mathbf{( \% )}$ \\
\hline C-Organik & 45,06 \\
Total N & 0,31 \\
Total P & 0,07 \\
K & 0,28 \\
\hline
\end{tabular}

\section{Pengukuran pH tanah}

Pengamatan $\mathrm{pH}$ tanah sebelum diinkubasikan dan sesudah diinkubasikan disajikan Tabel 5 . Dari Tabel 5 terlihat hasil analisis $\mathrm{pH}$ tanah sebelum diinkubasikan didapatkan hasil $\mathrm{pH}$ tanah dalam kategori Masam. Ini dapat disebabkan karena bahan induk tanah berasal dari tuff vulkan masam sehingga $\mathrm{pH}$ tanah pada sampel tanah sawah vulkanis rendah. Dan telah terjadi peningkatan setelah diinkubasikan selama 2 minggu, akan tetapi peningkatan ini belum mengubah kategori tingkat kemasaman tanah. Hal ini dapat disebabkan karena 
terjadinya pengikatan logam yang terdapat pada tanah baik oleh bantuan biochar maupun oleh pengkhelatan yang dilakukan oleh bakteri penghasil siderofor.

Tabel 5. Perbandingan $\mathrm{pH}$ tanah sebelum dan sesudah inkubasi

\begin{tabular}{ccc}
\hline Sampel & $\begin{array}{c}\text { pH Sebelum } \\
\text { Inkubasi }\end{array}$ & $\begin{array}{c}\text { pH Tanah } \\
\text { setelah } \\
\text { diinkubasi }\end{array}$ \\
\hline S0B0 & 4.96 & 5.31 \\
S0B1 & 4.99 & 5.53 \\
S1B0 & 4.98 & 5.31 \\
S1B1 & 4.95 & 5.47 \\
S2B0 & 4.98 & 5.18 \\
S2B1 & 5.20 & 5.19 \\
\hline
\end{tabular}

\section{Pengamatan Fe tanah}

Pengamatan Fe tanah dilakukan sebelum dan sesudah inkubasi dan disajikan pada Tabel 6 serta Gambar 3a dan 3b. Dari Tabel 6 terlihat pemberian isolat bakteri penghasil siderofor dan di tambahkan biochar sekam pagi mampu menurunkan secara nyata kandungan Fe total dan $\mathrm{Fe}{ }^{3+}$ pada tanah sawah vulkanis dibandingkan dengan perlakuan tanpa isolat dan tanpa biochar.Kombinasi terbaik terlihat pada penambahan $10 \mathrm{ml}$ isolat yang dicampurkan dengan biochar sekam padi. Pengkhelatan fe dalam keadaan teroksidasi. Siderofor memiliki afinitas yang tinggi terhadap unsur Fe (Kf >1030). Bakteri penghasil siderofor mengikat unsur Fe di luar dinding sel dan selanjutnya $\mathrm{Fe}$ diangkut ke dalam membran sel melalui reseptor spesifik.

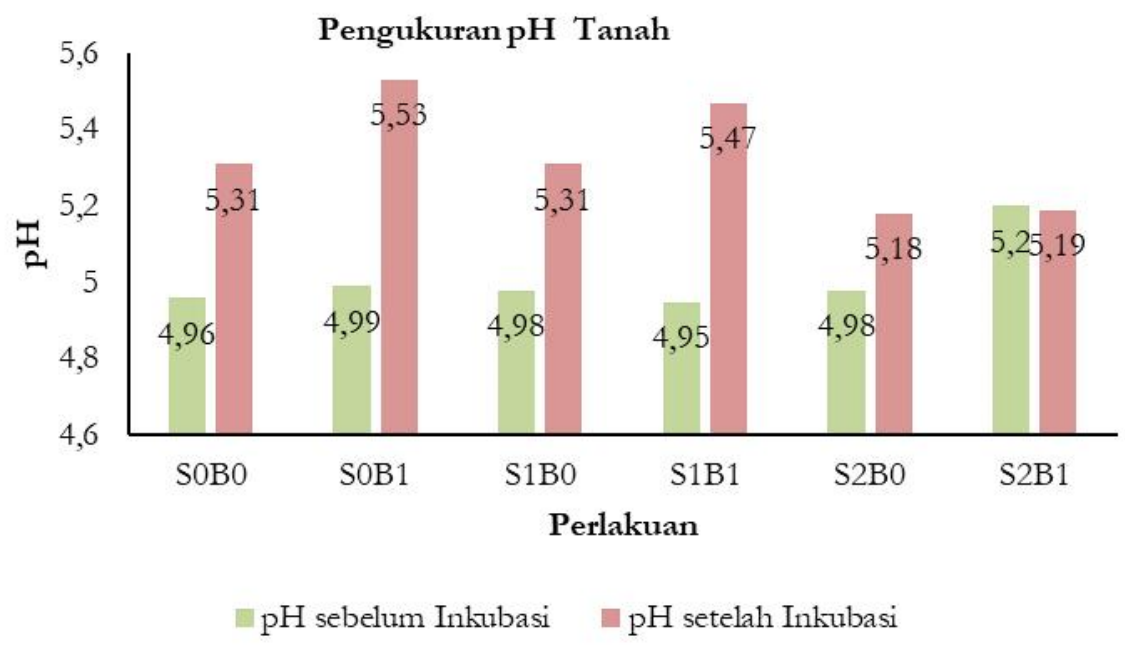

Gambar 2. Grafik perubahan $\mathrm{pH}$ tanah sebelum dan sesudah inkubasi.

Tabel 6. Kadar Fe tanah sebelum dan setelah inkubasi.

\begin{tabular}{cccccc}
\hline No & Perlakuan & $\begin{array}{c}\mathbf{F e}^{3+} \\
\text { Sebelum } \\
\text { Inkubasi }\end{array}$ & $\begin{array}{c}\text { Fe+3 } \\
\text { Sesudah } \\
\text { Inkubasi }\end{array}$ & $\begin{array}{c}\text { Fe-total } \\
\text { Sebelum } \\
\text { Inkubasi }\end{array}$ & $\begin{array}{c}\text { Fe total } \\
\text { Sesudah } \\
\text { Inkubasi }\end{array}$ \\
\hline 1 & S0B0 & 220 & $113 \mathrm{c}$ & 285 & $195 \mathrm{a}$ \\
2 & S0B1 & 193 & $144 \mathrm{~b}$ & 268 & $168 \mathrm{~b}$ \\
3 & S1B0 & 206 & $178 \mathrm{a}$ & 287 & $201 \mathrm{a}$ \\
4 & S1B1 & 214 & $78.3 \mathrm{~d}$ & 277 & $97 \mathrm{c}$ \\
5 & S2B0 & 209 & $76 \mathrm{~d}$ & 290 & $99 \mathrm{c}$ \\
6 & S2B1 & 216 & $85 \mathrm{~d}$ & 289 & $95 \mathrm{c}$ \\
\hline
\end{tabular}

Keterangan: Angka yang diikuti oleh huruf yang berbeda adalah berbeda nyata menurut DMRT pada taraf nyata $5 \%$. 
Kelompok utama dari siderofor adalah asam hidroksamat, senyawa yang mampu mengikat ion logam besi. Siderofor adalah senyawa berbobot molekul rendah yang mampu mengkhelat besi $\left(\mathrm{Fe}^{3+}\right)$, dan responsif untuk pelarutan serta pengangkutan elemen ini ke dalam sel bakteri (Sharma dan Johri, 2003). Pengiatan $\mathrm{Fe}$ secara tidak ansung dapat mengurangi serangan patogen serta secara tidak lansung dapt melepaskan posfat yang terfiksasi oleh Fe. Pengkhelatan Fe berdampak pada peningkatan $\mathrm{pH}$ tanah.

a.

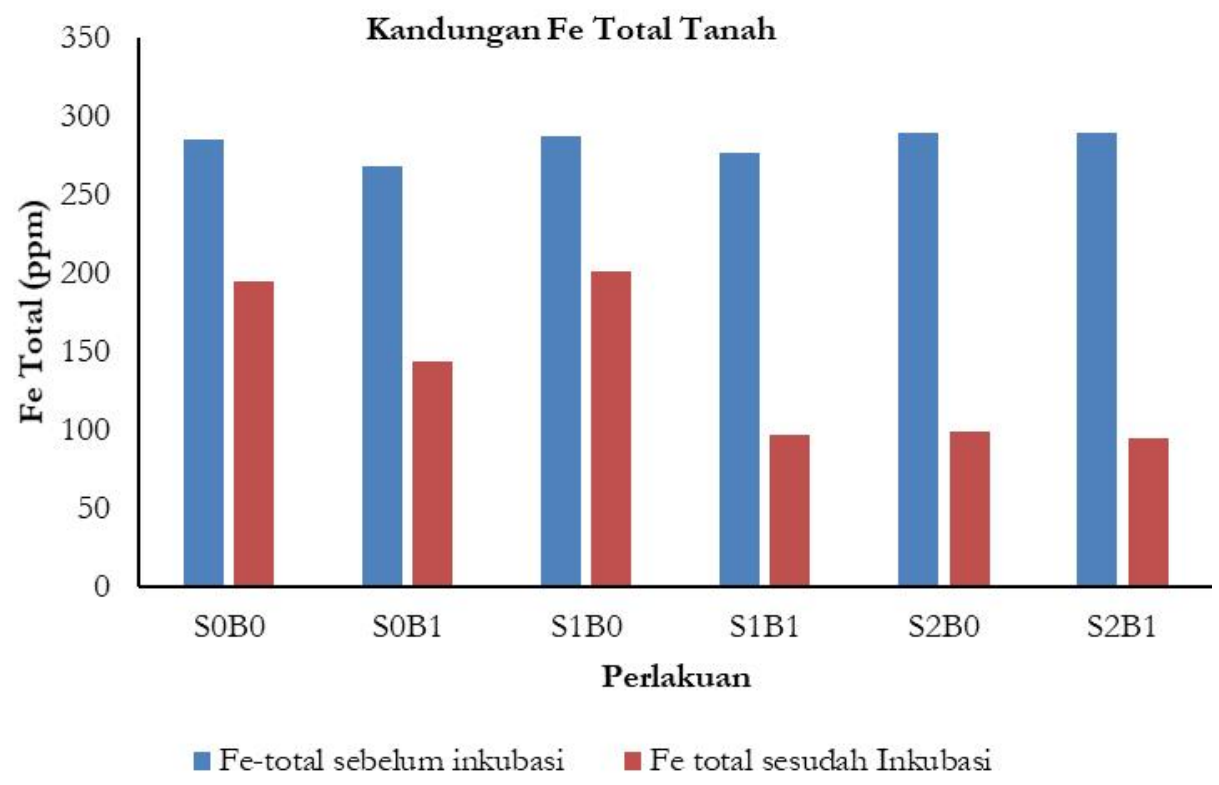

b.

Kandungan $\mathrm{Fe}^{+3}$

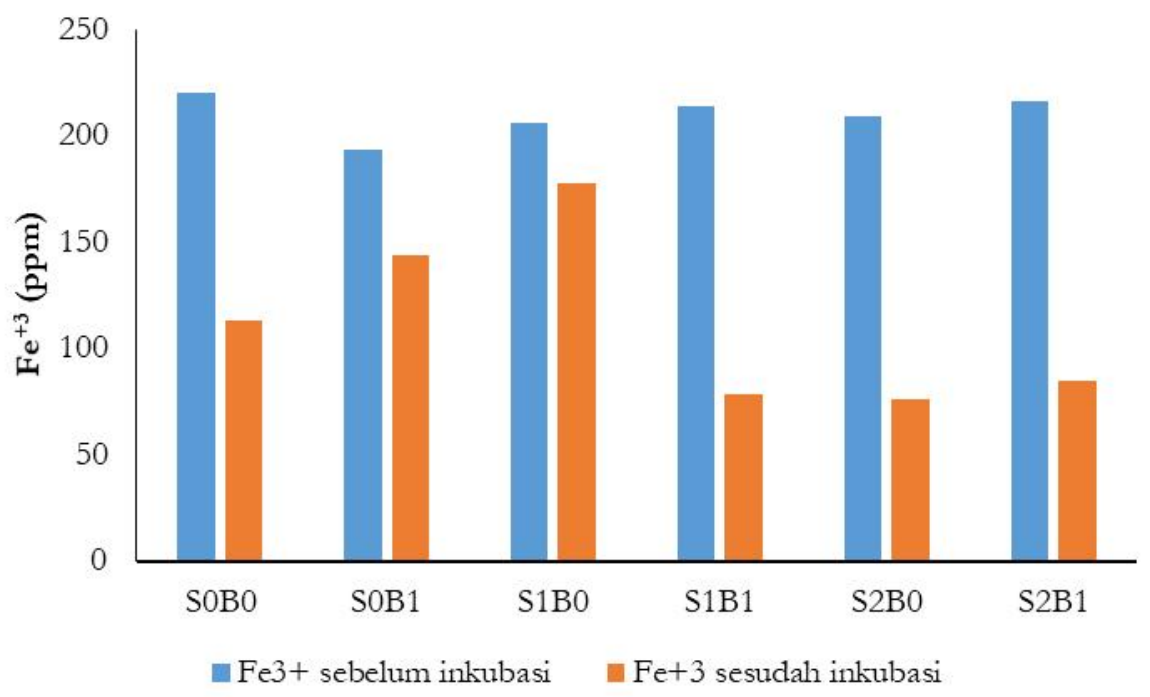

Gambar 3. Kandungan Fe di dalam tanah sawah vulkanis (a) Fe total dan (b) Fe ${ }^{3+}$ 


\section{Kesimpulan}

Dari hasil penelitian didapatkan bahwa pemberian isolat Bacillus Sp. sebagai bakteri penghasil siderofordan menggunakan media tumbuh biochar sekam padi telah mampu mengkhelat Fe pada tanah sawah dalam keadaan teroksidasi dan kombinasi terbaik terlihat pada penambahan $25 \mathrm{ml}$ isolat yang ditumbuhkan pada 25 gram biochar sekam padi.

\section{Ucapan Terima Kasih}

Penulis mengucapkan terimakasih kepada Kemenristek Dikti dan Universitas Andalas atas dukungan dana penelitian melalui Program PKM.

\section{Daftar Pustaka}

Badan Pusat Statistik. 2018. Sensus Penduduk 2018. Jakarta: Badan Pusat Statistik. $126 \mathrm{Hal}$

Datnoff, L.E., Rodrigues, F.A. and Seebold, K.W. 2007. Silicon and plant disease. In: Datnoff L.E.; Elmer, W.H.; Huber, D.M. (Ed.). 2007. Mineral Nutrition and Plant Disease. St. Paul: The American Phytopathological Society Press,. p.233-246.

Fiantis, D., Nelson, M., Shamshuddin, J., Goh, T.B. and Van Ranst, E. 2010. Leaching experiments in recent tephra deposits from talang vulkano (West Sumatra), Indonesia. Geoderma 158: 161-172.

Gani, A. 2009. Biochar Penyelamat Lingkungan. Warta Penelitian dan Pengembangan Pertanian 31: 15-16.

Neilands J. B. 1981. Iron absorption and transport in microorganisms. Annual Review Nutrition $1: 27-46$.
Nurida, N.L., Dariah, A. dan Rachman, A. 2010. Efikasi Formula PembenahTanah Biochar dalam Berbagai Bentuk (Serbuk, Granul, dan Pelet) dalam Meningkatkan Kualitas Lahan Kering Masam Terdegradasi.Prosiding seminar nasional sumberdaya lahan pertanian. Bogor 30 Nov - 1 Des 2010. Buku II. Konservasi lahan, pemupukan dan biologi tanah.

Pusat Penelitian dan Pengembangan Tanah dan Agroklimat. 2004. Tanah Sawahdan Teknologi Pengelolaannya. Badan Penelitian dan PengembanganPertanian. Departemen Pertanian: Bogor. $328 \mathrm{Hal}$

Sharma, A. and Johri, B.N. 2003. Growth promoting influence of siderophore-producing Pseudomonas strains GRP3A and PRS9 in maize (Zea mays L.) under iron limiting conditions. Microbiology Research 158(3): 243248.

Tanaka, A. and Tadano, T. 1972. Potassium in relation to non toxicity of the rice plant. Potash Review 21:1-12. 